IRSH 49 (2004), Supplement, pp. I9-40 DOI: I0.1017/So02085900400I622

(C) 2004 Internationaal Instituut voor Sociale Geschiedenis

\title{
Framing, Transnational Diffusion, and African- American Intellectuals in the Land of Gandhi
}

\author{
SEAN CHАв О T
}

Summary: Most of the contentious-politics scholars who pioneered the study of framing in social movements now also recognize the importance of transnational diffusion between protest groups. Interestingly, though, they have not yet specified how these two processes intersect. This article, in contrast, explores the framingtransnational diffusion nexus by highlighting three historical moments of interaction between African-American intellectuals and Gandhian activists before Martin Luther King, Jr traveled to India in 1959. After briefly reviewing the relevant literature, it illustrates how three different types of "itinerant" AfricanAmerican intellectuals - mentors like Howard Thurman, advisors like Bayard Rustin, and peers like James Lawson - framed the Gandhian repertoire of nonviolent direct action in ways that made it applicable during the American civil rights movement. The final section considers possible implications for social movement theory and fertile areas for further research.

In February 1959, a few years after the Montgomery bus boycott had anointed him as a prophet of nonviolence, Martin Luther King, Jr arrived in India to talk with fellow disciples of Gandhi and witness the effects of the Indian independence movement. He and his wife, Coretta, toured the country, had dinner with Prime Minister Jawaharlal Nehru, visited Gandhi's ashrama (self-sufficient communes), participated in conferences, and attended numerous receptions in their honor. During their four-week stay in India, the Kings discussed Gandhian nonviolent action with native experts like Dr Radhakrishnan, India's Vice-President; Jayaprakash Narain, a contemporary protest leader; and G. Ramachandran and R.R. Diwakar of the Gandhi Smarak Nidhi (Gandhi Memorial Trust). ${ }^{\mathrm{I}}$ Upon return to the United States, Martin Luther King, Jr wrote an article for Ebony, the popular African-American magazine, describing the journey's personal impact:

It was wonderful to be in Gandhi's land, to talk with his son, his grandsons, his

I. Swami Vishwananda, "I Go Round With The Kings", in William R. Miller, With the Kings in India: A Souvenir of Dr Martin Luther King's Visit to India, February-March 1959 (New Delhi, 1959), pp. 2-7. 
cousins and other relatives; to share the reminiscences of his close comrades, to visit his ashrama, to see the countless memorials for him and finally to lay a wreath on his entombed ashes at Rajghat. I left India more convinced than ever before that nonviolent resistance is the most potent weapon available to oppressed people in their struggle for freedom. ${ }^{2}$

Following his pilgrimage to "the Land of Gandhi", all doubt about King's Gandhian credentials vanished and in the early i960s he became the civil rights movement's most prominent intellectual and "framing specialist". ${ }^{3}$ As their indisputable leader, he encouraged participants in the AfricanAmerican freedom struggle to adopt and apply the Gandhian repertoire of nonviolent direct action in the United States. ${ }^{4}$

King's interaction with Gandhian scholars and activists in India was crucial for his legitimacy and effectiveness as the civil rights movement's leading representative. It invested his interpretations of the social problem in need of change (racial segregation in the United States), his views on who or what was to blame for this situation (white supremacy), his ideas about means and ends for challenging the status quo (nonviolence and integration), and his calls for collective action campaigns with credibility and persuasive power. At the same time, King's journey also contributed to the dissemination of the Gandhian repertoire from the Indian independence movement to the American civil rights movement. Theoretically, therefore, his pilgrimage to India was a vivid example of how framing and transnational diffusion intersect - a subject that has not received sufficient scholarly attention. ${ }^{6}$

To explore the framing-transnational diffusion nexus, I start with a brief review of existing social movement theories. Then, I discuss three specific "moments" of interaction between African-American intellectuals and Gandhians in India, and their effects on African-American frames and applications of the Gandhian repertoire in the United States. This empirical section illustrates that King's trip was not an isolated event, but occurred after numerous other African-American intellectuals had preceded him. It also points to the importance of creative framing for constructing transnational linkages between social movements embedded

2. James M. Washington (ed.), I Have a Dream: Martin Luther King, Jr, Writings and Speeches that Changed the World (San Francisco, CA, I986), p. 43.

3. Charles Kurzman and Lynn Owens, "The Sociology of Intellectuals", Annual Review of Sociology, 28 (2002), pp. 63-90; Ron Eyerman and Andrew Jamison, Social Movements: A Cognitive Approach (Cambridge, I99I); Robert D. Benford and David A. Snow, "Framing Processes and Social Movements: An Overview and Assessment", Annual Review of Sociology, 26 (2000), pp. 6 I I -639.

4. Sean Chabot, "Crossing the Great Divide: The Gandhian Repertoire's Transnational Diffusion to the American Civil Rights Movement" (Ph.D., University of Amsterdam, 2003).

5 . Of course none of this would have been possible (at least not at the same level of intimacy) if King and his Indian hosts had not spoken the same language, English.

6. Benford and Snow, "Framing Processes". 
in different cultural and historical contexts. The final section considers the relevance of my empirical findings for the subjects discussed in this supplement and suggests several lines of future research.

\section{FRAMING AND TRANSNATIONAL DIFFUSION IN SOCIAL MOVEMENT THEORY}

Both framing and transnational diffusion are now popular subjects of investigation in the field of contentious politics, but so far scholars have not studied how these two processes overlap. Research on collectiveaction frames and framing dynamics took off in the mid-1980s, with the pioneering work of David Snow, Robert Benford, and their colleagues. They helped incorporate Erving Goffman's social psychological concept into social movement theory by focusing on movement actors as "signifying agents actively engaged in the production and maintenance of meaning for constituents, antagonists, and bystanders or observers". ${ }^{7}$ Based on this perspective, they and others emphasize that "popular intellectuals" are responsible for three core interpretive tasks: diagnostic framing refers to the identification and attribution of a social problem; prognostic framing to the articulation of possible strategies for solving this social problem, given certain environmental opportunities and constraints; and motivational framing to the construction of compelling "vocabularies" for sustained social protest. ${ }^{8}$ Snow and Benford have also sparked considerable interest in the strategic alignment of collective-action frames with potential constituents or resource providers. These alignment processes include: frame bridging, the linking of previously unconnected frames regarding a particular issue; frame amplification, the reinterpretation of existing values or beliefs; frame extension, the expansion of a social movement organization's frames beyond its initial interests; and frame transformation, the generation of new public understandings and cultural meanings. 9 Since the mid-r990s, leading theorists recognize that cultural framing is a central dynamic in the emergence and development of

7. Ibid. Erving Goffman, Framing Analysis: An Essay on the Organization of Experience (New York, I974), p. 2I defines frames as "schemata of interpretation" that allow individuals (and groups) "to locate, perceive, identify, and label" events in their lives and the external world.

8. See e.g., Robert D. Benford, “'You Could Be the Hundredth Monkey': Collective Action Frames and Vocabularies of Motive within the Nuclear Disarmament Movement", Sociological Quarterly, 34 (1993), pp. 195-216; William A. Gamson, "The Sociological Psychology of Collective Action", in Aldon D. Morris and Carol M. Mueller (eds), Frontiers in Social Movement Theory (New Haven, CT, I992), pp. 53-76; David A. Snow and Robert D. Benford, "Ideology, Frame Resonance, and Participant Mobilization", International Social Movement Research, I (1988), pp. 197-218; idem, "Master Frames and Cycles of Protest", in Morris and Mueller, Frontiers; James M. Jasper, The Art of Moral Protest (Chicago, IL, I997).

9. David A. Snow et al., "Frame Alignment Processes, Micromobilization, and Movement Participation", American Sociological Review, 5 I (1986), pp. 464-48 I. 
social movements, together with political opportunities and mobilizing structures. ${ }^{10}$

Research on transnational diffusion between social movements is a more recent development. In 1993, Doug McAdam and Dieter Rucht broke new ground by concentrating on how contentious ideas and practices spread across borders, between similar transmitting and receiving protest groups. Building on the classical diffusion theory of Everett Rogers, and the findings of "world society" scholars like John Meyer and David Strang, they propose several guidelines for analyzing the influence of American New-Left students on their German counterparts. ${ }^{\text {II }}$ They suggest that receivers must define themselves as equivalent to transmitters and speak the same language; that the timing and pace of the receiving movement must lag behind those of the transmitting movement; that the two social movements must share common social contexts, ideologies, tactics, organizational forms, and cultural items; and that specific interpersonal and media-based channels of communication must link receivers to transmitters. ${ }^{\mathrm{I}}$

In the past decade, the number of publications on this subject has grown rapidly. But most of them still rely on the approach of McAdam and Rucht, emphasizing that transnational diffusion tends to flow along established channels of interaction, involve similar groups of transmitters and receivers, link similar social settings, and consist of adaptive emulation within a given political system. ${ }^{\mathrm{I}} 3$ The majority of empirical studies, moreover, continue to focus almost exclusively on the dissemination of information and tactics among Western activists - that is, among or between American and European activists. ${ }^{14}$

Io. Doug McAdam et al., Comparative Perspectives on Social Movements: Political Opportunities, Mobilizing Structures, and Cultural Framing (Cambridge, [etc.], 1996).

I I. Everett M. Rogers, Diffusion of Innovations (New York, 1995, 4th edn); David Strang and John W. Meyer, "Institutional Conditions for Diffusion", Theory and Society, 22 (1993): pp. 487-5II.

I 2. Doug McAdam and Dieter Rucht, "The Cross-National Diffusion of Movement Ideas", Annals of the American Academy of Political and Social Science, 528 (1993), pp. 56-74, 66, 7 I. I 3. David Strang and Michael W. Macy, "In Search of Excellence: Fads, Success Stories, and Adaptive Emulation", American Journal of Sociology, I07 (2001), pp. 147-1 82.

I4. See e.g., Marco G. Giugni, "The Cross-National Diffusion of Protest", in Hanspeter Kriesi et al. (eds), New Social Movements in Western Europe: A Comparative Analysis (Minneapolis, MN, I995), pp. I8I-206; Sarah A. Soule, "The Student Divestment Movement in the United States and Tactical Diffusion: The Shantytown Protest", Social Forces, 75 (1997), pp. 855-882; David Strang and Sarah A. Soule, "Diffusion in Organizations and Social Movements: From Hybrid Corn to Poison Pills", Annual Review of Sociology, 24 (1998), pp. 265-290; Sidney Tarrow, Power in Movement: Social Movements and Contentious Politics (Cambridge, [etc.], 1998, 2nd edn); Doug McAdam, “Initiator' and 'Spinoff' Movements: Diffusion Processes in Protest Cycles", in Mark Traugott (ed.), Repertoires and Cycles of Collective Action (Durham, NC, 1995), pp. 217-239; Doug McAdam, Sidney Tarrow, and Charles Tilly, Dynamics of Contention (Cambridge, 200I). Cf. Sean Chabot and Jan Willem Duyvendak, "Globalization 
The main exception is recent work by Snow and Benford, which criticizes the approach of McAdam, Rucht, and other influential scholars, arguing that transnational diffusion may also involve the construction of new channels of interaction, between different social movements and environments. ${ }^{\text {IS }}$ They stress that the spread of contentious ideas and practices often requires creative agency, by individual and collective receivers seeking fundamental change in the existing power structure, and discuss Western as well as non-Western cases.

Following the lead of Snow and Benford, my earlier work introduces an alternative theoretical framework for studying transnational diffusion between social movements. ${ }^{16}$ It highlights the role of "critical communities" in overcoming mainstream stereotypes and the contribution of underlying relational mechanisms like brokerage and appropriation. Critical communities, according to Thomas Rochon, are networks of popular intellectuals who "have developed a sensitivity to some problem, an analysis of the sources of the problem, and a prescription for what should be done about the problem". ${ }^{17}$ Their members make the adoption of foreign protest methods possible by employing them to develop new oppositional discourses or organize collective action campaigns. Brokerage, moreover, represents the formation of new or revitalization of old ties between transmitters and receivers, while appropriation reflects the ways that receivers mobilize traditional or new institutions to implement foreign protest methods in their own contexts. ${ }^{18}$

Recent scholarship on framing protest and transnational diffusion between social movements has produced useful insights. Yet none of these studies focuses explicitly on the interrelationships between these two processes. Even Snow and Benford, who have called for more attention to

and Transnational Diffusion between Social Movements: Reconceptualizing the Dissemination of the Gandhian Repertoire and the 'Coming Out' Routine”, Theory and Society, 3 I (2002), pp. 697-740; Sean Scalmer, "The Labor of Diffusion: The Peace Pledge Union and the Adaptation of the Gandhian Repertoire", Mobilization, 7 (2002), pp. 269-286.

I 5. David A. Snow and Robert D. Benford, "Alternative Types of Cross-national Diffusion in the Social Movement Arena", in Donatella della Porta et al. (eds.), Social Movements in a Globalizing World (London, I999), pp. 23-39. As Snow and Benford, "Framing Processes", pp. I4-Is put it: "framing activity is most relevant to social movement diffusion processes when [...] the conditions of similarity or compatibility between transmitters and potential adopters are not given but are problematic and in need of construction".

r6. Chabot, "Crossing the Great Divide"; Chabot and Duyvendak, "Globalization and Transnational Diffusion between Social Movements"; Sean Chabot, "Transnational Diffusion and the African-American Reinvention of the Gandhian Repertoire", in Jackie Smith and Hank Johnston (eds), Globalization and Resistance: Transnational Dimensions of Social Movements (Lanham, MD, 2002), pp. 97-I I4.

17. Thomas Rochon, Culture Moves: Ideas, Activism, and Changing Values (Princeton, NJ, I998), p. 22.

I8. McAdam, Tarrow, and Tilly, Dynamics of Contention, pp. 26, 45-48. 
this important subject, have not done so themselves. ${ }^{19}$ The following empirical section is an initial attempt to fill this gap in the literature. Continuing the narrative of the introduction, it discusses three historical moments of interaction between African-American intellectuals and Gandhians in India. By concentrating on how such moments enabled the spread of Gandhian protest methods between very different social movements and environments - from an Asian independence movement to a Western civil rights movement - it highlights a rare yet momentous case where successful transnational diffusion largely depended on innovative framing, and vice versa.

\section{AFRICAN-AMERICAN JOURNEYS TO INDIA AND FRAMING AT HOME}

As I noted in the introductory paragraphs, King's trip to India in 1959 illustrates the influence of transnational diffusion on domestic framing, on the one hand, and the significance of domestic framing for transnational diffusion, on the other. At the same time, though, it also tends to overstate the role of one individual actor and underestimate broader historical processes. It glosses over the fact that two contextual factors strongly affected King's decision to travel to India and meet with "authentic" Gandhians. First of all, members of his inner circle started urging him to visit the Gandhian repertoire's country of origin as early as 1956. Although King had read several of Gandhi's books as a university student, other African-American intellectuals knew much more about the techniques and implications of nonviolent direct action than he did. By taking the trip to the land of Gandhi, and writing about his experiences, he demonstrated to himself, other civil rights activists, and the outside world - that he was a competent Gandhian in his own right. And secondly, King actually followed in the footsteps of several African-American predecessors, who first ventured on the long journey in 1935. Inspired by the Indian independence movement, and particularly the Salt March campaign in I930, these pioneers set out to meet Gandhi and ask whether his methods were relevant for fighting racial discrimination in the United States. Whereas most observers and scholars stress King's personal debt to Gandhi, therefore, I emphasize that he built on the shoulders of earlier generations of African-American intellectuals and activists.

\section{Howard Thurman, liberation theology, and nonviolent direct action}

The first African-American leader to embark on a pilgrimage to India was Howard Thurman, professor in the School of Religion at Howard

19. Snow and Benford, "Framing Processes", pp. I4-15. 
University (Washington DC), the premier black college in the United States and an important training ground for "race rebels". ${ }^{20}$ In 1935 , the International Committee of the YMCA and YWCA invited him to head an African-American delegation (which included his wife, Sue, as well as Reverend Carroll and his wife) to the Student Christian Movement in Burma, Ceylon, and India. Initially, Thurman wanted to turn down the invitation because he did not want to represent a religious institution American Christianity - that condoned racial segregation. But after talking with Miriam Slade, an English member of Gandhi's ashram, he decided to take advantage of this unique opportunity to tour the Indian subcontinent and meet with the famous proponent of nonviolent direct action. $^{2 \mathrm{I}}$

Thurman was certainly not the only African-American intellectual interested in the Gandhian repertoire of contention. During the I920s, prominent figures like W.E.B. Du Bois and Marcus Garvey had frequently referred to the Indian independence movement and its leader to support their respective views on international racial solidarity. And the dramatic Salt March in 1930, during which Gandhi and millions of Indians engaged in civil disobedience of British laws, had received a great deal of coverage in African-American journals and newspapers. ${ }^{22}$

Before 1935, however, many African-American intellectuals admired Gandhi's efforts in India without considering adoption of his ideas or practices in the United States. They generally felt that the moderate methods of the National Association for the Advancement of Colored People (NAACP) - such as lobbying for legal reform, publicity campaigns, and court action - were more practical and effective in the American context than Gandhian protest on a mass scale. Although he was not a radical or an activist, Thurman believed that existing methods for desegregating the Christian church and American society were inadequate. He looked to Gandhi and India for new insights on how to reinvent Christianity and achieve first-class citizenship for the African-American minority. ${ }^{23}$

20. See Robin D.G. Kelley, Race Rebels: Culture, Politics, and the Black Working Class (New York, 1994).

21. Howard Thurman, With Head and Heart: The Autobiography of Howard Thurman (San Diego, CA, 1979), pp. 103-107.

22. Sudarshan Kapur, Raising Up a Prophet: The African-American Encounter with Gandhi (Boston, MA, 1992).

23. In the early I920s, Thurman was a youth leader of the YMCA and the Christian student movement, and toward the end of the decade he became the first African-American board member of the pacifist Fellowship of Reconciliation (FOR). As a follower of the Quaker mystic, Rufus Jones, Thurman focused on the spiritual affirmation of personal experiences without denying the relevance of religious, cultural, class, and racial barriers in the social world; Walter Earl Fluker and Catherine Tumber (eds), A Strange Freedom: The Best of Howard Thurman on Religious Experience and Public Life (Boston, MA, I998), pp. I-I7. 
During their visit, the four African-American Christians interacted with various Indian audiences and activists. After a public lecture at Law College in Ceylon, for example, the chairman asked Thurman why he had come to India as representative of a religion that had participated in the slave trade and continued to deny the African-Americans minority its civil rights. Thurman answered that he had not come to defend the Christian church or to proselytize:

It is far from my purpose to symbolize anyone or anything. I think the religion of Jesus in its true genius offers me a promising way to work through the conflicts of a disordered world. I make a careful distinction between Christianity and the religion of Jesus [...]. From my investigation and study, the religion of Jesus projected a creative solution to the pressing problem of survival for the minority of which He was a part in the Greco-Roman world. When Christianity became an imperial and world religion, it marched under banners other than that of the teacher and prophet of Galilee. Finally, the minority in my country that is concerned about and dedicated to experiencing that spirit that was in Jesus Christ is on the side of freedom, liberty, and justice for all people, black, white, red, yellow, saint, sinner, rich, or poor. They, too, are a fact to be reckoned with in my country. ${ }^{24}$

In other parts of the Indian continent, people confronted the AfricanAmerican delegation with this question about the relationship between Christianity and racial segregation as well. Besides participating in numerous public meetings, the members of Thurman's group also went to Shantiniketan, the international university of Rabindranath Tagore, the famous Indian poet and Nobel Prize winner. Here, they met with Dr Singh, the head of the division of Oriental studies, who shared their ideal of crossing religious, cultural, social, and political barriers. In Hyderabad, moreover, they talked about Gandhian nonviolence with Sarojini Naidu, the poetess who had played such an important role during the Salt March campaign. ${ }^{25}$

For the Thurmans and the Carrolls, the highlight of the trip was undoubtedly their encounter with Gandhi in Bardoli. As Thurman writes in his autobiography, after greeting them warmly, the Indian leader immediately began asking a series of profound questions about slavery, voting rights, public education, lynching, discrimination, and so forth, demonstrating a keen interest in African-American history. ${ }^{26}$ When they discussed practical means for achieving fundamental social change, Gandhi told them that:

The effectiveness of a creative ethical ideal such as nonviolence [...] depends upon

24. Thurman, With Head and Heart, p. II 4 .

25. Ibid., pp. I28-I29, I 36. See also, Gene Sharp, Gandhi Wields the Weapon of Moral Protest:

Three Case Histories (Ahmedabad, 1960).

26. Thurman, With Head and Heart, p. I32. 
the degree to which the masses of the people are able to embrace such a notion and have it become a working part of their total experience. It cannot be the unique property or experience of the leaders; it has to be rooted in the mass assent and creative push. ${ }^{27}$

He added that, from what he had heard, the African-American minority was no less capable of sustained nonviolent direct action than the Indian population. ${ }^{28}$ At the time, though, talk about a nonviolent social movement by African Americans seemed remote to Howard Thurman, who was particularly eager to hear Gandhi's views on religion. Before leaving the ashram, therefore, he inquired: "What do you think is the greatest handicap to Jesus Christ in India?". Gandhi responded: "Christianity as it is practised, as it has been identified with Western culture, with Western civilization and colonialism. This is the greatest enemy that Jesus Christ has in my country - not Hinduism, or Buddhism, or any of the indigenous religions - but Christianity itself." 29 Thurman could not have agreed more and, from that moment on, he set out to develop an alternative Christian discourse that did focus on removing the worldwide color line.

The interaction of Thurman and his group with leading intellectuals and activists in India affected the framing of the Gandhian repertoire in the United States in several significant ways. In the first place, after returning to Howard University, Thurman's own thinking and writings emphasized the need to create a form of religion that avoided the racist and imperialist foundations of Western Christianity and contributed to human community among diverse ethnic groups and cultures. ${ }^{30}$ In his most important work, Jesus and the Disinherited, Thurman suggests that such an activist gospel should build on the ethics of Jesus Christ because:

His message focused on the urgency of a radical change in the inner attitude of the people. He recognized fully that out of the heart are the issues of life, that no external force, however great and overwhelming, can at long last destroy a people if it does not first win the victory of the spirit against them. ${ }^{3 \text { I }}$

Inspired by his meeting with Gandhi in 1936, this "liberation theology frame" expresses basic insights of the Gandhian repertoire in familiar Christian language. ${ }^{32}$

Secondly, the positive experiences of the Thurmans and Carrolls stimulated other members of their critical community to embark on the same pilgrimage. At the end of 1936, Benjamin Mays, dean of Howard University's School of Religion, and Channing Tobias, secretary of the

27. Ibid., p. I33.

28. Collected Works of Mahatma Gandhi (CWMG) (New Delhi, 1999), vol. 68, pp. 237-238.

29. Thurman, With Head and Heart, p. I35.

30. Fluker and Tumber, A Strange Freedom, pp. 200-2 Io.

31. Howard Thurman, Jesus and the Disinherited (Nashville, TN, 1949), p. 21.

32. Fluker and Tumber, A Strange Freedom, pp. 2 I I-2 I9. 
YMCA's Colored Men's Department, went to India to participate in the World Conference of the YMCA and talk with Gandhi at his ashram. The Indian leader told them that nonviolent direct action was an active rather than a passive force, that its effects were three-fourths invisible and only one-forth visible, and that African Americans should experiment with it in their own settings. 33 And in 1947, after becoming dean of Howard University's School of Religion in 1940, William Stuart Nelson also traveled to the Indian subcontinent and discussed protest strategies with Gandhi. Following their return to the United States, these AfricanAmerican theologians further developed Thurman's frame in articles, books, and lectures, illustrating how the Gandhian repertoire contributed to a Christian approach to race relations. ${ }^{34}$

Finally, and most importantly, the African-American theologians' journeys to India set the stage for a new "nonviolent direct action frame". In I942, one of Thurman's students, James Farmer, decided to translate his mentor's activist Christian discourse into practice. Soon after graduating from Howard University, Farmer drew on his knowledge of the Gandhian repertoire to formulate a detailed plan for challenging American racial segregation, and shared it with his colleagues at the Fellowship of Reconciliation (FOR). Like Thurman, he asserted that existing means of protest - such as those of the NAACP - were inadequate and called for the adaptation of Gandhian methods to conditions in the United States:

Certain societal and cultural differences between the United States and India, and certain basic differences between the problems to be dealt with in the two countries, militate strongly against an uncritical duplication of the Gandhian steps in organization and execution. The American race problem is in many ways distinctive, and must to that extent be dealt with in a distinctive manner. Using Gandhism as a base, our approach must be creative in order to be effectual. 35

Like Thurman (as well as Mays, Tobias, and Nelson), moreover, Farmer argued that the only way to reach the African-American masses was through the "The Negro Church". ${ }^{6}$ Guided by classic works on Gandhi's methods like Richard Gregg's The Power of Nonviolence (Philadelphia,

33. CWMG, vol. 70, pp. 26I-264, 269; Benjamin Mays, Born to Rebel (New York, 1971), pp. I $55-157$.

34. Idem, "The Color Line Around the World", Journal of Negro Education, 6 (1937), pp. I34I43; Lawrence Edward Carter, Sr (ed.), Walking Integrity: Benjamin Mays, Mentor to Martin Luther King, Jr (Macon, GA, I998); William Stuart Nelson (ed.), The Christian Way in Race Relations (New York, I948); William Stuart Nelson, "Satyagraha: Gandhian Principles of NonViolent Non-Cooperation”, Journal of Religious Thought, Autumn-Winter (1957-1958), pp. I 5-24; Keith D. Miller, Voice of Deliverance: The Language of Martin Luther King, Jr and Its Sources (New York, I992); Chabot, "Crossing the Great Divide", pp. I I5, I32.

35. James Farmer, Lay Bare the Heart: An Autobiography of the Civil Rights Movement (Fort Worth, TX, 1985$),$ p. 356.

36. Ibid., p. 359 . 
PA, I934) and Krishnalal Shridharani's War Without Violence (New York, 1939), he and his pacifist friends in Chicago then employed a nonviolent direct action frame to organize and mobilize the first Gandhian campaigns in the United States. These campaigns, co-sponsored by the FOR, subsequently inspired activists in other parts of the country to initiate their own Gandhian campaigns and led to the foundation of the Congress of Racial Equality (CORE) in I 942, with Farmer as president. 37 Thurman's interpretation of the Gandhian repertoire thus not only influenced other African-American theologians in his critical community, but eventually also prepared the soil for small-scale and experimental applications of Gandhian nonviolent direct action in American communities.

\section{Bayard Rustin, nonviolent direct action, and the civil rights movement}

Farmer was not the only African-American framing specialist involved in CORE. Bayard Rustin, a fellow organizer of the religious-pacifist FOR, was also a prominent strategist and participant of the first explicitly Gandhian protest organization in the United States. Like Farmer, he spent most of the I940s leading workshops on nonviolence throughout the country and applying the Gandhian repertoire to fight racial segregation. ${ }^{38}$ During World War II, he took part in CORE's "sit-ins" against the discriminatory practices of Northern restaurants and, in 1947, he helped initiate the Journey of Reconciliation to test federal laws on interstate public transportation in the American South. ${ }^{39}$

But as the Cold War began heating up at the end of the decade, the nonviolent direct-action frame developed and implemented by Farmer, Rustin, and other leaders could no longer motivate CORE groups into confrontational Gandhian campaigns. In a domestic climate averse to any type of radicalism, most supporters of African-American civil rights preferred to engage in more moderate forms of protest, like those promoted by the NAACP. $4^{\circ}$ Faced with an inhospitable environment at home, and inspired by the experiences of Thurman, Mays, and Nelson, Rustin decided to continue his study of the Gandhian repertoire in India.

37. August Meier and Elliott Rudwick, CORE: A Study in the Civil Rights Movement, 1942I968 (New York, I973).

38. Rustin's career as a peace activist started in 1937, when he joined the Emergency Peace Campaign to prevent a new world war. During the orientation sessions Rustin first met Muriel Lester, a fellow Quaker and the British ambassador for the International Fellowship of Reconciliation, and from then on he devoted himself to pacifism and racial justice. Unlike Farmer, Rustin was involved in a wide variety of protest groups and social causes, both American and international ones; Jervis Anderson, Bayard Rustin: Troubles I've Seen (New York, 1997), pp. 40-68.

39. Ibid., pp. I I3-I 24 .

40. Meier and Rudwick, CORE. 
When Rustin arrived in Delhi at the end of 1948, Gandhi was no longer alive. Yet many veterans of the Salt March and other Gandhian events were still around, eager to discuss the Indian leader's legacy. Accompanied by Muriel Lester, FOR's international ambassador and a long-time supporter of Indian independence, Rustin first met Devadas, the son of Gandhi. Then he attended the All-India Congress Party convention and talked with Prime Minister Jawaharlal Nehru and Deputy Prime Minister Sardar Patel, who shared their perspectives on Gandhi's contributions. And after leaving Delhi, he came in contact with various young Gandhian intellectuals, engaging in heated debates about nonviolent direct action principles and strategies. One of them, Devi Prasad, later noted that:

He met us and gave us some idea of what was going on in the world of nonviolence in the United States. He sang spirituals that won everybody's heart. The Martin Luther King phenomenon had not yet started, but we got a very profound impression that Bayard was doing Gandhi's work in North America. ${ }^{\mathrm{I}}$

Prasad and other native Gandhians also appreciated the fact that, during his tour of the country, Rustin adopted Indian customs and wore Gandhian clothing..$^{2}$

Rustin's interactions with local intellectuals and activists were quite different from those of his predecessors. While Thurman, Mays, Tobias, and Nelson had visited India at the height of Gandhi's influence, Rustin came after the country had gained national independence and Gandhi had passed away. With Nehru and the Indian National Congress party in power, the Gandhian repertoire was no longer considered a practical means for achieving social or political change. Unlike the African-American theologians, therefore, Rustin was actually quite negative about the prospects for effective nonviolent direct action in India, although he admired the commitment of Gandhian youth groups. Ironically, Indian intellectuals and activists like Devi Prasad now felt that the American environment for sustained Gandhian campaigns was more favorable than their own. ${ }^{43}$

After coming back, Rustin became widely known as one of the foremost experts on the Gandhian repertoire in the United States. Some pacifist friends even started calling him "Rustiji", just as Indian activists had referred to their leader as "Gandhiji". During the early i950s, he applied the nonviolent direct-action frame to various domestic and international causes. He joined the Peacemakers, a group opposing the American development of nuclear weapons and preparations for war. He traveled to Africa to express his support of African independence movements. And in 1953, after leaving the FOR, he became executive secretary of the War

4I. Anderson, Bayard Rustin, p. I3 I.

42. Ibid., p. I32.

43. Ibid., p. I34. 
Resisters' League (WRL). ${ }^{44}$ But by far his most significant contribution to the interpretation and application of the Gandhian repertoire began in 1956, as the strategic advisor of King and the Montgomery bus boycott.

Impressed by the nonviolent spirit of the African-American community in Montgomery, Rustin introduced himself to King and started working for the Montgomery Improvement Association (MIA) in February I 956.45 MIA leaders, in turn, recognized the expertise of Rustin and began taking the strategic implications of the Gandhian repertoire more seriously. They learned how to use familiar Christian language to communicate fundamental Gandhian principles to their constituency. They agreed to use positive terms like "bus protest" instead of "bus boycott," which implied an illegal restraint of the local economy. And King himself relied on Rustin to write many of the texts that helped establish his reputation as a proponent of Gandhian methods and a prophet of nonviolence. Rustin drafted "Our Struggle" for the April I956 issue of the journal Liberation and helped revise Stride Toward Freedom, King's autobiographical account of the Montgomery bus boycott. ${ }^{46}$

One of the main lessons Rustin had learned in India was that the impact of sporadic symbolic nonviolent protest tended to be limited. Following the Montgomery bus boycott, therefore, Rustin thought of ways to expand a single Gandhian campaign into a sustained social movement for ending the system of racial segregation in the South. In I957, he helped create the Southern Christian Leadership Council (SCLC), persuaded King to become its leader, and developed a suitable frame for guiding the civil rights movement in the South. Drafted by Rustin, the SLCL's statement of purpose outlines the main elements of the Gandhian "civil rights movement frame":

SCLC activity revolves around two main focal points: the use of nonviolent philosophy as a means of creative protest; and securing the rights of the ballot for every citizen [...]. The basic tenets of Hebraic-Christian tradition coupled with the Gandhian concept of satyagraba - truth force - is at the heart of SCLC's philosophy [...]. SCLC believes that the American dilemma in race relations can best and most quickly be resolved through the action of thousands of people, committed to the philosophy of nonviolence, who will physically identify themselves in a just and moral struggle [...]. SCLC sees civil disobedience as a natural consequence of nonviolence when the resister is confronted by unjust and immoral laws. 47

Besides identifying the appropriate means, it also highlighted the main end

44. Ibid., chs 8, 9, and I I.

45. Miller, Voice of Deliverance, pp. 95-96.

46. Anderson, Bayard Rustin, pp. I94, 209.

47. Francis L. Broderick and August Meier (eds), Negro Protest Thought in the Twentieth

Century (Indianapolis, IN, 1965), pp. 269-273. 
of the African-American freedom struggle: "The ultimate aim of SCLC is to foster and create the "beloved community" in America where brotherhood is a reality [...]. Our ultimate goal is genuine intergroup and interpersonal living - integration. Only through nonviolence can reconciliation and the creation of the beloved community be effected." 48 Although King would receive most of the credit, Rustin's role in formulating the original civil rights movement frame - and translating it into organized collective action - was no less crucial.

\section{James Lawson, student activists, and the civil rights movement}

Among the many students Rustin encountered in his nonviolent workshops during the I940s was James Lawson, a radical African-American pacifist. ${ }^{49}$ Lawson first learned about the Indian independence movement from reports in African-American newspapers like the Pittsburgh Courier, from sermons and essays by African-American theologians like Thurman and Mays, and from books by and about Gandhi. ${ }^{\circ}$ Yet it was Rustin who taught him how to translate these inspiring ideas into action. During the Korean War, Lawson served a year in federal prison as a conscientious objector and, in 1953 , he opted to complete his term as a fraternal worker in India. ${ }^{5 \mathrm{I}}$

During his three years on the Indian subcontinent, Lawson worked for the Methodist Church as a teacher at Hislop College in Nagpur. In his free time, though, he tried to learn as much as possible about the Gandhian repertoire and its implications. Besides discussing the independence movement with local students, he talked and interacted with prominent Gandhians such as Vinoba Bhave, now the country's primary symbol of nonviolence; J.C. Kumarappa, the famous Gandhian economist; and Asha Devi, one of the more militant Gandhian activists since 1947. He also participated in various conferences, workshops, and seminars held by Serva Seva Sangh, the nationwide organization devoted to continuing Gandhi's efforts. ${ }^{2}$

48. Broderick and Meier, Negro Protest Thought, pp. 272-273.

49. Lawson, son of an African-American Methodist minister, became a radical pacifist during his college years, after an encounter with FOR leader, A.J. Muste. As a university student, moreover, he read Gandhi's autobiography and became convinced that a Gandhian-Christian form of nonviolence was the best way of applying the New Testament in everyday life; Kapur, Raising Up a Prophet, p. I55.

50. James Lawson, videotaped interview by Steve York for the documentary A Force More Powerful, Los Angeles, 26 October 1998.

5. Kapur, Raising Up a Prophet, p. I55; Taylor Branch, Parting the Waters: America in the King Years 1954-63 (New York, I988), p. I43; David Halberstam, The Children (New York, 1998), pp. I 2, 47-49.

52. Kapur, Raising Up a Prophet, p. I55. 
Lawson derived two important insights from his experiences in postcolonial India. First of all, he realized that young students (like those at Hislop College) were more likely to engage in the kind of radical action required for achieving significant social change than well-known symbolic leaders (like Vinoba Bhave). And secondly, he observed that decentralized and "group-oriented" organizations encouraged the repressed community to belp itself, while centralized and "leader-oriented" organizations tended to act in name of the subordinated population. So when Lawson read about the Montgomery bus boycott in the Nagpur Times, he was impressed by the eloquence and influence of Martin Luther King, Jr, but also eager to expand the involvement of African-American students and other Southern communities. 53

In 1957, after returning to the United States, Lawson met King at Oberlin College in Ohio and, inspired by their conversation, decided to work as the FOR's secretary of race relations in the South. ${ }^{54}$ He settled in Nashville, Tennessee and became Chairperson of Direct Action of the Nashville Christian Leadership Council (NCLC), the SCLC's local branch. In 1958, he began organizing a series of community workshops on local forms of racial segregation and the power of nonviolent direct action. Most of the participants in these gatherings were students at African-American universities and members of African-American churches in Nashville. Initially, they just discussed the history of nonviolence, the responsibility of Christians, and the implications of Gandhian methods. After several months, however, they decided to test their knowledge in practice by experimenting with ways to desegregate the restaurants in downtown Nashville. Eventually, these talking sessions and preliminary efforts set the stage for Nashville's sit-in movement. 55

In February 1960, when students in Nashville joined the wave of sit-ins spreading across the South, they used Lawson's framing of the Gandhian

53. Lawson was not the only one to read about the Montgomery bus boycott in the Indian press. The mainstream newspaper Hindustan Times, for example, regularly published articles on what it called "Mass 'Gandhi-Type' Protest in Alabama" (Saturday, 3 March 1956, p. 5; see also Hindustan Times, Sunday, 23 December 1956, p. 7). Indian activists who continued to organize nonviolent direct action campaigns after Gandhi's death in 1948 , moreover, were inspired by the successful application of Gandhian methods during the African-American civil rights movement. Ram Manohar Lohia, for instance, came to the United States in 1964 to meet with SNCC students involved in the Freedom Summer campaign in Mississippi. Although his main purpose was to teach Gandhian strategy to young civil rights activists, Lohia also sought motivation for further activism at home; Edwin King, "Lohia and the American Civil Rights Movement", Gandhi Marg, 59 (197I), pp. 270-277. I leave the theoretical implications of such "crossfertilization" for future work.

54. Lawson, York interview; Halberstam, The Children, pp. i6-i7.

55. Ibid., pp. 90-92; John Lewis (with Michael D’Orso), Walking with the Wind: A Memoir of the Movement (New York, 1998), p. 86. 
repertoire to guide their campaign. ${ }^{56}$ Leading student activists like John Lewis, Diane Nash, James Bevel, and Bernard Lafayette faithfully implemented the rules of nonviolent direct action they had learned during his workshops. As Lewis describes in his autobiography, the night before the first sit-ins he and Lafayette drafted a code of behavior, based on the Gandhian principles emphasized by Lawson:

DO NOT:

I. Strike back nor curse if abused.

2. Laugh out.

3. Hold conversations with floor walker.

4. Leave your seat until your leader has given you permission to do so.

5. Block entrances to stores outside nor the aisles inside.

DO:

I. Show yourself friendly and courteous at all times.

2. Sit straight; always face the counter.

3. Report all serious incidents to your leader.

4. Refer information seekers to your leader in a polite manner.

5. Remember the teachings of Jesus Christ, Mahatma Gandhi, and Martin

Luther King. Love and nonviolence is the way. ${ }^{57}$

And in their interactions with the authorities, student activists employed the same Christian-Gandhian language as Lawson. When the local judge offered all those arrested the choice of paying a \$50 fine or serving thirty days in jail, Nash answered: "We feel that if we pay these fines, we would be contributing to and supporting the injustice and immoral practices that have been performed in the arrest and conviction of the defendants." 88

Instead of relying on the decisions of one dominant leader, moreover, they tried to reach consensus collectively and appointed different leaders for each event. And rather than merely representing the repressed minority in Nashville, they initiated an economic boycott of all downtown stores that directly involved the entire African-American community. ${ }^{59}$ In short, the student activists adopted each of Lawson's fundamental ideas about how to engage in Gandhian protest: express love in word and deed, "group-oriented" leadership, decentralized organizational style, and inclusion of the aggrieved population as a whole.

The influence of Lawson's civil-rights-movement frame was not limited to Nashville. In April 1960, delegates of sit-in groups throughout the South held a conference in Raleigh, North Carolina, and founded the

56. Aldon D. Morris, "Black Southern Sit-in Movement: An Analysis of Internal Organization”, American Sociological Review, 38 (1981), pp. 744-767; Clayborne Carson, In Struggle: SNCC and the Black Awakening of the I960s (Cambridge, 1981); Lewis, Walking with the Wind.

57. Lewis, Walking with the Wind, p. 98.

58. Ibid., p. 103.

59. Ibid., pp. 105-106. 
Student Nonviolent Coordinating Committee (SNCC). As a keynote speaker at the meeting, Lawson criticized traditional civil rights leaders (particularly those belonging to the NAACP) for concentrating on "fundraising and court action rather than developing our greatest resource, a people no longer the victims of racial evil who can act in a disciplined manner to implement the constitution". ${ }^{60}$ In the same speech, he identified the main goals of the sit-in movement: first of all, to make clear that racial segregation and prejudice is morally reprehensible; secondly, to assert that the current pace of social change and civil rights protest was too slow. ${ }^{6 \mathrm{I}} \mathrm{He}$ also drafted the SNCC's statement of purpose, highlighting the need for nonviolent means of collective action and expressing Gandhian principles in familiar Christian terms. ${ }^{62}$ And finally, Lawson encouraged the SNCC to adopt a policy of rotating leadership, to make collective decisions by consensus, and to focus as much on community development in the rural South as on symbolic protest and national exposure. ${ }^{63}$ By stimulating student activists to develop their own style of Gandhian protest and organization (which differed considerably from the "leader-oriented" style promoted by Rustin, King, and the SCLC), he helped the SNCC to become the most radical and innovative wing of the civil rights movement during the early i960s.

\section{THEORETICAL IMPLICATIONS AND SUGGESTIONS FOR FUTURE RESEARCH}

The preceding discussion of African-American itinerants and their influence at home does not tell the whole story. It does not account for the role of Indian intellectuals in the United States, for example, or for the contribution of Euro-American intellectuals. It neither considers crossfertilization of ideas and practices, nor relationships with sympathetic American groups, although both processes helped shape how the framing and transnational diffusion of the Gandhian repertoire evolved. ${ }^{64}$ And it does not pay much attention to the fact that both transmitters and receivers spoke the same language (which was, of course, the language of their respective oppressors). A comprehensive analysis would certainly have to incorporate such complex dynamics and relate specific empirical findings to social mechanisms like brokerage and appropriation. ${ }^{65}$ This article is

60. Broderick and Meier, Negro Protest Thought, p. 280.

61. Ibid., pp. $278-279$.

62. Ibid., pp. 273-274.

63. Carson, In Struggle; Charles M. Payne, I've Got the Light of Freedom: The Organizing

Tradition and the Mississippi Freedom Struggle (Berkeley, CA, 1995).

64. For more on these subjects, see Chabot, Crossing the Great Divide.

65. McAdam, Tarrow, and Tilly, Dynamics of Contention. 
merely a first step toward a more general explanation of framing protest and transnational diffusion between social movements.

But while they provide just a glimpse of the underlying processes, the three moments of interaction between African-American intellectuals and Gandhians in India were clearly crucial for the framing and transnational diffusion of the Gandhian repertoire. These encounters contributed directly to the interpretive tasks, alignment processes, and conditions for dissemination emphasized in the social movement literature.

The initial journeys of Thurman, Mays, and Tobias at the end of the I930s (and of Nelson in 1947) enabled the development of a Christian liberation theology frame, which offered a new diagnosis of American racial relations and a new prognosis for improving them. This frame not only transformed religious discourse, but also motivated Farmer and other young activists to engage in small-scale nonviolent direct action and, in I942, found CORE on the basis of the Gandhian repertoire.

In I949, CORE's Rustin decided to embark on the same pilgrimage as the African-American theologians. During his stay in India, he learned that Gandhi's ideas and practices were most effective in the context of a social movement. When the opportunity arose, therefore, he helped King and other Southern ministers create a Gandhian frame for guiding the American civil rights movement - with its own diagnoses, prognoses, and motivations for transforming the racial status quo. The successful application of this new frame in Montgomery symbolized the completion of the Gandhian repertoire's diffusion from India to the United States.

Meanwhile, Lawson lived in India, serving his sentence for conscientious objection during the Korean War. After coming back in 1956 , he began preparing inexperienced students in Nashville for militant sit-in campaigns, thereby extending the civil rights movement frame formulated by Rustin and popularized by King. In the early i960s, the diagnoses, prognoses, and motivations characterizing Lawson's frame underpinned the SNCC and allowed the civil rights movement to expand its application of the Gandhian repertoire.

The significance of these three moments grew as the African-American intellectuals who traveled to India, and the activists they influenced, forged close ties with each other. Farmer was a student of Thurman and Mays; Rustin was a colleague of Farmer; and Lawson, who had participated in Rustin's workshops, shared his knowledge and experience with Lewis, Nash, Bevel, Lafayette, and other students involved in the sit-ins. ${ }^{66}$ These African-American intellectuals and activists established their own linkages with King and the civil rights movement. Mays and Thurman (and, to a

66. These interpersonal ties were only the tip of the iceberg. Rustin and Farmer, for instance, shared the stage with Nelson and Tobias at a conference on the role of nonviolence for AfricanAmerican protest in I 943. See John H. Bracey, Jr and August Meier (eds), The Papers of A. Philip Randolph (Bethesda, MD, I990); Miller, Voice of Deliverance. 
lesser extent, Nelson and Tobias) became King's mentors. Rustin served as strategic advisor of King and the SCLC, while Farmer was an important role model. Lawson was both an admirer of King and his peer. Like Thurman, Mays, Tobias, Nelson, and Rustin, he encouraged the civil rights movement's leader to continue the African-American tradition of traveling to the land of Gandhi and meeting "real" Gandhians. And finally, the African-American students in Nashville, and later of the SNCC, represented the radical wing of the civil rights movement; they tried to persuade King to support militant rather than moderate forms of nonviolent protest.

The historical evidence demonstrates that pilgrimages to India before I959, and before King's rise to prominence, played an essential role in the African-American adoption of the Gandhian repertoire. Neither King's journey nor his interpretations and applications of Gandhi's protest methods would have been possible without the insights and efforts of his predecessors.

But what is the relevance of this single case study for social movement theory on the intersection between framing and transnational diffusion? Or, in other words, how does it help us understand the formulation of "ideas that inspire collective action" as well as the "flows of meaning" between local, national, and global fields of contention?

Following the lead of Snow and Benford, the majority of social movement scholars now take framing processes seriously. And inspired by the work of McAdam and Tarrow, among others, cutting-edge students of organized protest have recently started recognizing the relevance of transnational diffusion between activist groups. In this article, I have tried to move the field forward by focusing on several generations of "itinerant intellectuals", and by illustrating how the framing of foreign contentious methods is related to their transnational diffusion. Theoretically, my case study highlights at least four points with broader relevance.

First, social movement scholars usually assume that foreign ideas and practices enter the receiving country through diffusion, after which activists incorporate them into local discourses and strategies through framing. My case study indicates that these two processes are intricately related and, therefore, should not be analyzed separately. On the one hand, adopting the Gandhian repertoire from abroad increased the persuasive power of African-American frames for civil rights protest in the United States. On the other hand, transnational diffusion of the Gandhian repertoire succeeded because of interpretive constructs that stimulated the organization of nonviolent direct action - and eventually a Gandhian social movement - at home.

Second, my case study exemplifies the problematic implications of distinguishing sharply between the "West" and "non-West". It focuses on members of an African-American minority who traveled to India to learn 
about how to fight for civil rights in the United States. Categorizing such cases as primarily Western or non-Western does not make sense, because actors and processes in the core of the world system were inextricably related to actors and processes in the periphery, and vice versa. This does not mean that we should avoid analyzing cultural, political, economic, and social differences among groups, countries, or regions. I do suggest, however, that we should particularly stress the importance of framing for transnational diffusion when the differences between transmitters and receivers are apparent (as they were between Indian and African-American intellectuals). Historically, such cases are exceptional yet highly significant: although ideas and practices are more likely to spread between similar social movements and contexts, truly innovative ideas and practices often come from divergent social movements and contexts.

Third, this case study specifies who plays an important role in framing and transnational diffusion. It highlights three types of itinerant intellectuals that visited the country of origin, each with a unique relationship to the receiving social movement. The initial group of African-American travelers to India consisted of established theologians, who subsequently became mentors to movement leaders. Thurman, Mays, Tobias, and Nelson influenced King and other prominent figures in the civil rights movement, without participating in the protest campaigns themselves. Rustin was another type of itinerant intellectual: after returning to the United States, he served as an advisor to King and other leaders from within the civil rights movement (although from behind the scenes). And following his three years in India, Lawson evolved into an important peer of visible movement leaders like King. He helped found the SNCC, a movement organization that promoted and applied more radical forms of Gandhian action than dominant individuals or groups within the civil rights movement. My case study suggests that these three types of itinerant intellectuals - mentors, advisors, and peers - are crucial for translating intellectual insights from foreign expeditions into collective action with strong domestic roots. They are the "rooted cosmopolitans" that allow repressed groups to think globally and act locally. ${ }^{67}$

My case study's fourth theoretical point is that each type of itinerant intellectual has a distinct effect on the interpretation of foreign protest methods at home. African-American theologians (who served as King's mentors during the I950s and I960s) emphasized the relevance of the Gandhian repertoire for Christian discourse in the United States, while Farmer and fellow CORE activists used the Gandhian repertoire to engage in nonviolent direct action. Rustin, moreover, invoked Gandhi's ideas and

67. Sidney Tarrow, "Rooted Cosmopolitans: Transnational Activists in a World of States", paper presented at Amsterdam School for Social Science Research seminar, University of Amsterdam, 6 May 2003. 
practices to develop a leader-oriented civil rights movement frame that suited his role as advisor to King. And, as a peer of King, Lawson employed similar ideas and practices to formulate an alternative, grouporiented civil rights movement frame. The relationship between these frames was always tense and fluid. Religious discourse sometimes encouraged and other times discouraged radical action. "Leader-oriented" activists sometimes cooperated and other times disagreed with "grouporiented" activists. Thus, African-American intellectuals interpreted and applied the Gandhian repertoire in diverse ways; they did not adopt it to develop a uniform "master frame". ${ }^{68}$

Thought provoking as these theoretical arguments may be, they remain hypothetical. The question remains, for example, whether my approach applies only to transnational diffusion between different transmitters and receivers, or also to transnational diffusion between similar ones. To evaluate the validity and scope of my conceptual framework, social movement scholars need to apply it to numerous other empirical situations. In closing, therefore, let me just point to one historical and one contemporary case in which itinerant intellectuals figured (and continue to figure) prominently. I hope that fellow IRSH authors and students of contentious politics will join me in analyzing these and other cases in greater depth, and help me set the stage for a more general theory of framing protest and transnational diffusion between social movements.

The international women's movement of the late nineteenth and early twentieth century is an obvious historical example of activism beyond borders. ${ }^{69}$ Leila Rupp, for instance, describes how female activists from Europe and North America traveled across continents to attend meetings and conferences. ${ }^{70}$ These interpersonal encounters shaped the construction of an international collective identity and persuaded increasing numbers of women to fight for civil rights, world peace, and economic justice. At the time, though, these transnational networks consisted almost exclusively of Western women with similar, middle-class backgrounds. My approach could add new insights into this form of "traveling feminism" by focusing directly on the framing-diffusion nexus, highlighting linkages between different transmitters and receivers (from within as well as outside the West), distinguishing among various types of itinerant intellectuals, and specifying the latter's influence on the production of meaning at home. ${ }^{7 \mathrm{I}}$

68. David A. Snow and Robert D. Benford, "Master Frames and Cycles of Protest", in Aldon M. Morris and Carol M. Mueller (eds), Frontiers in Social Movement Theory (New Haven, CT, I992), pp. I33-I 55 .

69. Margaret Keck and Kathryn Sikkink, Activists beyond Borders: Transnational Activists in International Politics (Ithaca, NY, 1998).

70. Leila J. Rupp, "Constructing Internationalism: The Case of Transnational Women's Organizations, I888-1945”, The American Historical Review, 99 (1994), pp. I 57 I-I600.

7I. For more on the international women's movement of this era, see e.g., Richard J. Evans, The Feminists: Women's Emancipation Movements in Europe, America and Australasia I840-1920 
My theoretical framework should also apply to contemporary movements in which itinerant intellectuals clearly play a prominent role, such as the so-called Global Justice Movements (GJMs). Most researchers assume that the main framing specialists and activist networks in the GJMs - the struggles against corporate globalization that first reached a wide audience during the Battle of Seattle in I 999 and continue to challenge international capitalist institutions today - are located in the United States and Europe. ${ }^{72}$ Like the editors of this IRSH supplement, I seek to develop a more balanced perspective by paying particular attention to the influence of contentious ideas and practices originating in Asia, Africa, or South America. To what extent, for example, have American activists in the GJMs witnessed and learned from the innovative protest methods of their colleagues in the Brazilian landless movement (known as the MST)?73 By exploring the specific contributions of various itinerant intellectuals, social movement scholars should learn more about whether (and how) transnational flows of meaning involve cross-fertilization between non-Western and Western groups. As African-American intellectuals before and during the civil rights movement realized, creative framing can overcome the obstacles involved in transnational diffusion between social movements even if the political, social, economic, and cultural gaps between transmitters and receivers are vast.

(London, 1977), pp. 247-248; Bob Reinalda and Natascha Verhaaren, Vrouwenbeweging en Internationale Organisaties I868-1986 (Nijmegen, 1989); and Edith F. Hurwitz, "The International Sisterhood," in Renate Bridenthal and Claudia Koonz (eds), Becoming Visible: Women in European History (Boston, MA, 1977). For research on transnational advocacy networks among contemporary feminists outside of the West, see Millie Thayer, "Traveling Feminisms: From Embodied Women to Gendered Citizenship”, in Michael Burawoy et al. (eds), Global Ethnography: Forces, Connections, and Imaginations in a Postmodern World (Berkeley, CA, 2000), pp. 203-233.

72. See e.g. Jackie Smith, "Globalizing Resistance: The Battle of Seattle and the Future of Social Movements", in Jackie Smith and Hank Johnston (eds), Globalization and Resistance: Transnational Dimensions of Social Movements (Lanham, MD, 2002), pp. 207-228; Tarrow, "Rooted Cosmopolitans"; Nick Crossley, "Global Anti-Corporate Struggle: A Preliminary Analysis”, British Journal of Sociology, 53 (2002), pp. 667-691.

73. Sue Branford and Jan Rocha, Cutting the Wire: The Struggle of the Landless Movement in Brazil (London, 2002). 